\title{
The Relationship between Speaking and Writing Performance in an Indonesian Senior High English Foreign Language (EFL) Classroom
}

\section{Alsuna: Journal of Arabic and English Language}

\section{Lilik Maskuroh Hadah \\ Universitas Islam Negeri Sunan Ampel \\ @1lilikmasykuroh@gmail.com}

\section{Sayyidatul Maghfiroh}

Universitas Islam Negeri Sunan Ampel @ syayyida3@gmail.com

\section{Naza Zulmia Humairoh Universitas Islam Negeri Sunan Ampel ⓝazahumaira18@gmail.com}

\section{Wahyu Nur Ahadah \\ Universitas Islam Negeri Sunan Ampel Q wahyunurakhada2000@gmail.com}

\section{Keywords:}

Correlation

Speaking Skill

Writing Skill

\section{Article Information:}

Submitted: 06 June, 2020

Accepted: 15 November, 2020

Approved: 28 November, 2020

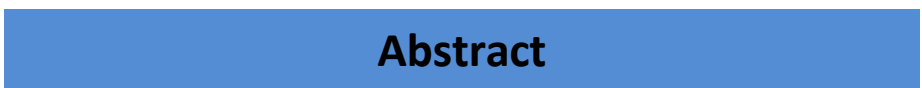

Purpose - This research aims to figure out the relationship between those two productive skills focusing on four aforementioned crucial aspects in language learning.

Design/methodology/approach - This study used a crosssectional quantitative method with 32 English Education Department students in the 6th semester at Universitas Islam Negeri Sunan Ampel Surabaya who have already been experienced in spoken and written class to be the participants. In terms of gaining the data, It used pictured cued interviews and answer the open-ended question related to the best way in finding a job and give their opinion within 30 minutes. Both of the tests were adapted from the TOEIC sample test from the Educational Testing Service (ETS). Finally, use SPSS 2.2 for the data analysis.

Findings - The result shows that the organization gains the highest rate or simply as the most related part among the other language learning. Furthermore, the correlation between the two productive skills also shows a moderate correlation.

Originality/value - It simply said that speaking and writing show an insignificant correlation with the organization as the most related part of language learning.

Paper type - Research paper

\section{Introduction}

One of the second language acquisition (SLA) researcher's most important tasks is exploring and completely identifying the skills required in learning a second language along with the variables affecting the acquisition of the $L 2$ by using those four skills (M. D. Hubert 2008). The fact that the language practices are mostly allocated to one of the four categories of language usage: reading, writing, speaking, and listening makes the number of research emerged in exploring the issues of it. 
The most common research spread out nowadays has focused within a single category of skill, including how the strategy, learning style, and also discuss among student and teacher perspectives about each skill. In the last seven decades, as (Indrilla and Ciptaningrum 2018) \& (Kucukoglu 2015) highlighted that the writing and reading skills which involve the approaches in enhancing students' writing ability and how to make effective reading strategies. While research from (Wulandari, Harahap, and Hati 2019), it focuses on the analysis of students' listening learning styles. The aforementioned research has been explored using any possible methods of data collection, such as qualitative using observation, questionnaire, and document analysis as well as quantitative. Those articles become evidence that most of the researchers only considered one skill and strategy.

Exploring how the four skills are interlinked and integrated is much less common. Although the fact of those four skills is interlinked such listening is the foundation for speaking, reading is a source for listening, listening and speaking facilitate reading and writing, and vice versa (Nan 2018a). Understanding how the language skills are interlinked becomes crucial, especially exploring the relationship between both productive skills-speaking and writing. It is because instead of their significant roles as a communication modality, both productive skills are still often wisely valued as the determinant of learners' ESL/EFL mastery whether in the classroom context or real-life situations. Therefore, it is important to examine its relationship between two skills since it may be useful as the teacher's basis for designing its best course for writing which might, in turn improve another skill at speaking

Besides that, the consistent phenomena connected to this productive skill also appear. The fact that the theory of speaking and writing walked in the same direction that interrelated and caused positive transfer to each other. Such speaking activates writing indirectly, which means that the improvement of writing can be dependent on the development of writing skills only, but the Oral acquisition of language also can help the improvement of (Quan 2014). (Quan 2014) makes most people say that written language is the written form of what people speak, but the case is not so simple. The evidence from the daily situation in a spoken and written classroom context at UINSA shows the distinction. By finding enormous students who are excellent in written form whether showing ideas, pieces of advice, or even some comments; expressing things orally also is preserved by them. They prefer to write all the things down. Furthermore, some students who can speak like a native, being active in every 
classroom discussion, also the majority of their way to write is intact. This case is immediately proportional to the aforementioned theory.

Fortunately, the empirical investigation concerning the relationship between speaking and writing abilities for people learning a second language ("L2") has been popular over the decades such as (Mangelsdorf 1989); (Weissberg 2006); (M. Hubert 2008); Zhang, 2013; (Bambang Yudi Cahyono 2017); (Mahmudah 2019); (Naser and Latiff 2019). The result of each research was also quite similar such as (M. D. Hubert 2008). They claimed even though this two language skill has the same function that is to communicate with others to subsist and to maintain certain interpersonal relationships, but as two skills of language, speaking and writing have their characteristics and they have crucial differences in many aspects which require different learning and teaching methods to deal with them respectively. The result from (Weissberg 2006) also states that the similarity as the productive skill may not be unintentional, not causal. While (Mahmudah 2019); (Bambang Yudi Cahyono 2017), (Naser and Latiff 2019)have the same focus, which takes EFL as the subject of the study.

The result from (Mahmudah 2019); (Bambang Yudi Cahyono 2017) show result shows that there is a perfect agreement between Indonesian EFL students' speaking skill and their writing proficiency. This indicates that speaking exercises that are accompanied by writing activities help students generate speech for successful communication with greater accuracy and fluency. While (Naser and Latiff 2019) claim that the frequency of the association between the abilities of second-language writers to communicate and write is very limited along with the various types of expertise in both writing and speaking expertise of which there was no generalizable pattern in this course. the similarity between those productive skills The previous studies mostly highlighted a single category to link the correlation such us in terms of the organization itself or vocabulary using the particular text. Despite draw parallels between the learning that is in this of vocabulary, organization, and grammar at once even though its importance in being considered as successful learners.

The correlation between writing and speaking abilities has gained a position throughout the discourse of the public and the existing perception of the similarities that could exist between them which is still place in the quite wide investigation instead of just being the user. Since The lack of basic knowledge of the relation between these two modalities of language development, it can be amazing for several people especially in terms of considering the media or way to develop for both speaking and writing which usually created 
somehow as a similar form whenever it isn't always walk in the same direction. Furthermore, attempting to draw parallels between the language learning categories also hard to find; furthermore, many of them place the connection between writing and speaking is not incorporated in the classroom but rather treated as distinct phenomena to be taught and assessed differently.

Based on the aforementioned previous studies, they demonstrated how speaking and writing correlate with each other, discussing both of the skills are related to the particular part rather than in the general point of view or area. Meanwhile, this study addressed deeply to find out the relationship performance and the things or factors that influence both two productive skills, speaking and writing, in terms of organization, vocabulary, and grammar that may exist between these two language skills in the EFL classroom context. , the researchers also try to determine the student's correspondence between both of the skills, especially that occurred in a pedagogical environment.

\section{State of The Arts and Distinguish}

Discussing the focus of the research, the researcher conveyed two research questions. The first research question of this research is "Do the students perform differently between speaking and writing English in terms of organization, diction/vocabulary, and grammar?" Furthermore, the second one is "How the students speaking do and writing ability show the correspondence?"

\section{The relationship between Listening, Reading, Speaking and Writing in SLA}

As a result of an empirical investigation from (Nan 2018b), she stated that the four language skills have a close relationship. it sets up as a system in which is interlinked and integrated one another such as the fact that listening is the foundation for speaking, reading is a source for listening, listening, and speaking facilitates reading and writing, and vice versa. The four language skills should stick together joint organically and merged to ensure English teaching becomes integrated and comprehensive. That it can obtain the finest integration of language learning and improve English teaching becomes more efficient (Crystal, Goh, and Doyle 2015).

Increasing the four language skills efficiently, all of the language proficiency should be risen to reach the goal of language development. The undertakings of the researches have widely been created to teach four basic skills for over 60 years related to the second and 
foreign languages (Bozorgian 2012). However, language presents many intentions, and the role of language enacts enormously. Identified as the necessities nowadays, the four requisites in language or generally known as the four skills that are reading, writing, listening, and speaking dedicate a vital role in any language learning aspect (Sadiku 2015).

\section{Speaking and Writing Development for Native Speakers (Children and Adult)}

(Suryantari 2018) stated that second language acquisition (SLA) refers to the process of learning another language after the native language has been learned with the process of internalizing and making sense of a second language after establishing the first language. In assigning the process of learning language, (Gass, S. M. \& Selinker, n.d.) delivered several phenomena of early language development in the speaking skill. Those are babbling, cooing, and crying (Krashen 2002). In babbling, it consists of consonant-vowel sequences prevalently (e.g., bababa, dadada). Related to early language development, the (Development 2010) also stated that language develops in three scopes that can be learned by children: - words or vocabulary - sentence structure or grammar - speech sounds. Baby learns much of language sounds in his first year. At 5 months old, your baby already understands several new words. Besides, from the age of six months, they will attempt to communicate and start to commence exchanges the information. meanwhile, children's development in writing, (Sulzby and Teale 1985) demonstrated young children of the writing development, they can develop their path for instance scribbling, making a letter, invented spelling phonetically, using strings of the letter. Scribbling depicted the proof of intentional valuation that happens about at the age of 18 months. Furthermore, in 2 years or three months more, they attempt to drawing and writing simply, such as writing the letter.

(Florez 1999) declared that in the adult age of developing speaking skills, they should allow entering the lesson or speaking task for increasing their speaking. In the speaking task class, described several tasks; those are imitative, intensive, responsive, transactional, interpersonal, and extensive. Therefore, in the speaking lesson, firstly they can discuss a certain topic, vocabulary, and phrases. The second is they conduct small talk in a casual situation. Then, they can get clarity and accuracy some structure of the language. The third is question and comment. After that, they can exchange information, interview, debates, or role-play. The last is they can offer monologues, for example oral reports/summary and short speeches. Besides, adult's writing development also can be intensified from the several tasks; however, (Rosenfeld, Courtney, and Fowles 2004) claimed there are several tasks to increase 
adult's writing: trust sources appropriately; regulate ideas; utilize grammar based on the standard written English; summarize essential information; incorporate information from multiple sources; evolve well-focused related relevant reasons and examples; write clearly with smooth transitions; improve the correctness, coherence, and clarity; independent work to compose text. in considering the sequences of the task, (Joy Kreeft Peyton and Kirsten Schaetzel 2016) established that research in the university programs for students learning English has discovered that students obtain different amounts of instruction in those skills in writing courses, even it focuses on academic writing.

\section{Things are required for Writing Ability}

(Fatmawati, Santosa, and Ariyanto 2013) argued that writing skill is the act of expressing something through the utilization of the language system. When writing, there are two prominent areas, namely "what to write or the content to write and how to write it or the way to write" (Mahadi and Jafari 2012). It addresses language skills are intended to become the ability to play the rules of language ordinarily; meanwhile, the linguistic system or knowledge of the word/content points to the writer's knowledge background about the subject to write (Perera et al. 2015). Dealing with the foremost scope of writing development, (Fati 2013) also demonstrates that language/linguistic proficiency is the individual ability to speak or perform in an acquired language in the form of a wa written way.

\section{Things are required for Speaking Ability}

To assess the success of conveying messages through speaking, (Young 2002) elicited successful speech in how people say and understand in real connections with other people that can create the interactive nature of such communications. However, (Askia and Manurung 2016) conveyed that productive (speaking) skill in the oral mode that the students did not only have the interaction skill with the others well but also they should pronounce the words to support the communication. Another notion is (Leong and Ahmadi 2017), they stated there are two keys elements of the communicative approach, especially in speaking ability particularly. Those are fluency and accuracy. (Hughes 2002) testifies the first key element; fluency is the ability to speak to create an understanding atmosphere for communication. The second factor of speaking performance is accuracy. Based on the (Hedge 2000), fluency is the ability to answer by pronouncing the sounds, connecting the words and phrases, and utilizing stress and intonation coherently (Mazouzi 2013). 


\section{Current Theories on the Relationship between Speaking and Writing}

(Elvita and Indrasari 2017) demonstrate that there is a correlation between students' speaking and writing ability, especially in high school students. In that research, the researcher conducted the study through descriptive text. The study depicted that speaking and writing ability are connected. Another one is Cayer and Sacks's research that have inspected the writing of eight L1 English students having basic writing skills which studying at a community college. Their writing depicted the various features of the language of speaking; it exhibits the oral language ability greatly influenced their written ability. Because the oral and written languages at a different level were not completely differentiated even at the students' level of the university (Baba, Takemoto, and Yokochi 2013).

The relationship between speaking and writing has long been apprehended to be primarily indirect with speech placing the foundation for writing. In another term, the development of children's writing depends on their knowledge related to spoken language to deliver meaning. The role of speech has also been conceded in bolstering second language writing development (Weissberg 2006). Writing has been found out as a more sophisticated code that jacks up speech. Even though speech appears to require comparatively less plain teaching and writing expansion entails instruction.

\section{Methodology}

The purpose of the research is to analyze the correlation between the two productive skills, writing and speaking. The researcher used a cross-sectional quantitative method, as (Gans, Scott, and Wu 2019) claimed that the method is beneficial to describe characteristics that exist in a community and not to determine the cause and effect. This research strategy emphasizes the correlation between speaking in writing in three major categories such as vocabulary, organization, and grammar, along with elaborated the finding with the generated theories.

The participants in this study were selected using random sampling to choose 32 out of 90 students in the 7th semester at English Education Department UINSA willingly participated in this study. Simple random sampling was used in that the classification of gender is not the main consideration, but this research only focuses on equal probability and those who were willing to be the research participants. The participants have experienced in joining Spoken and Written class in their previous semester. 
There were two instruments used in this research, including writing and speaking tests. Both of the tests were adapted from the TOEIC sample test from the Educational Testing Service (ETS). On the writing test, the students had to answer one open-ended question related to giving their opinion about the best way in finding a job. They had to finish their work not more than 30 minutes and should write a minimum of 300 words. The essays were assessed based on several points, including content, coherence, syntax, and vocabulary used. Every point that was assessed had $1-5$ scales. Meanwhile, in measuring the speaking ability, the students were tested to describe a picture related to the people's activity in the market in as much detail as they could. Participants have a limited time in giving their respond approximately 45 seconds. The researchers gave a rate of the participants from several scales $1-5$ based on their speaking performances. The speaking performance in the test was seen according to the student's Pronunciation, fluency, syntax, and vocabulary selection.

In conducting the research, the researcher did it all online. It starts with creating a statement to explain the purpose of research and having an agreement with the participants to collect the data. All of the participants are treated the same way, giving them a similar purpose statement since they are agree to devote their time to answer the researcher question. Before this, the researcher gave an explanation related to the purpose of the research and explained the procedure and instruction for doing the test. , the researcher gave the test (TOEIC), including writing and speaking skills. Installing, the participant wrote an essay related to their opinion on how to find the best job in 300 words during the modern 30 minutes. Then, the researcher asked them to do it, and it should be resent to the researcher. After the result tests of the participants were gathered, the researcher analyzed the result supporting SPSS that involving vocabulary skill, organization, and grammar structure.

To answer the first research question, do the students perform differently between speaking and writing English in terms of organization, diction/vocabulary, and grammar?" The researcher focused on the three elements which used to assess them that are in term of vocabulary, grammar, and organization and analyzed it to know the element from those three aspects that has the strongest relationship. While to answer the second research question, how the students speaking do and writing ability show the correspondence? The researcher combined the final score from the four aspects that were assessed in both speaking and writing that are organization, content, syntax, and vocabulary to know the correlation output from the two productive skills. 


\section{Findings and Discussion}

The first research question is "Do the students perform differently between speaking and writing English in terms of organization, diction/vocabulary, and grammar?" Tables 1 and 2 will depict the result of the gathered data. From table 1 the mean and standard deviation for speaking addressed 3 measurements. Those are the organization, vocabulary knowledge, and grammatical aspect.

\begin{tabular}{|c|c|c|c|}
\hline & N & Mean & Std. Deviation \\
\hline Organization & 32 & 71.2500 & 14.31219 \\
\hline Vocabulary & 32 & 67.5000 & 17.41338 \\
\hline Grammar & 32 & 70.0000 & 13.44043 \\
\hline Valid N & 32 & & \\
\hline (listwise) & & & \\
\hline
\end{tabular}

Table 1: Means and Standard Deviation in Speaking

In table 1 above, the organization in speaking skill is highest rather than vocabulary and grammar in the mean analysis. It represents 71.2500; however, the standard deviation shows 14.31219. In an organization, it includes the speaker manage the way in speaking, for instance flow of the speaking is smooth, quick and continuous, self-correct and respond the clue, occasional hesitation. Regarding the vocabulary aspect, the value in table 1 is 67.5000 with the highest value of standard deviation, 17.41338, and the vocabulary can be told that deal with some parts, for example, good and wide range, appropriate vocabularies, words and expression, interesting and good respond; nonetheless, some of the participants have the adequate and normal vocabulary to respond in speaking. Besides, with a value of the mean of 70.0000 and the lowest value of standard deviation 13.44043, grammar covers no grammatical error in speaking, speaker self-correction, a minor grammar error but some of them still address the structure incorrectly.

\begin{tabular}{|c|c|c|c|}
\hline & N & Mean & Std. Deviation \\
\hline Organization & 32 & 76.8750 & 15.33234 \\
\hline Vocabulary & 32 & 70.0000 & 12.44342 \\
\hline
\end{tabular}




\begin{tabular}{|l|c|c|c|c|}
\hline \multicolumn{1}{|c|}{ Grammar } & 32 & 71.2500 & 15.18701 \\
\hline Valid & $\mathbf{N}$ & 32 & \\
\hline (listwise) & & \\
\hline
\end{tabular}

Table 2: Means and Standard Deviation in Writing

Meanwhile, regarding another productive skill, writing, the organization has the highest value in mean 76.8750 either in standard deviation 15.33234. In writing, the organization can be specified in some aspects such as the flow of the writing, good transition, and appropriate punctuation. In vocabulary, the value expresses mean is 70.0000 and the

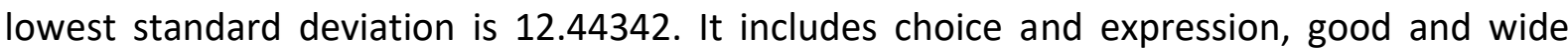
range, appropriate vocabularies, interesting and good response furthermore, grammar the use in the mean is 71.2500 and 15.18701 as the standard deviation. In grammar aspects, it embodies the grammatical error or not in speaking, speaker self-correction, Minoa $r$ error in grammar but some of them sometimes still address the structure into incorrectly sum up, based on the aforementioned result, it can be indicated that students generated both of the productive skills which have the relationship in the difference of the particular points in written spoken-way and oral way addressed initial aspects can be called organization, vocabulary, and grammar especially in the ESL/EFL or pedagogical field.

Research Question 2. The second research question is "How the students speaking do and writing ability show the correspondence?" that explained in the second analysis used SPSS .2 .2 but, it uses the final score of the combination from the four aspects were assessed in both speaking and writing that are organization, content, syntax and, vocabulary. The followithe ng is the result in detail.

\begin{tabular}{|c|c|c|c|c|}
\hline & & & Speaking & Writing \\
\hline \multirow[t]{4}{*}{ Spearman's rho } & Speaking & $\begin{array}{l}\text { Correlation } \\
\text { Coefficient }\end{array}$ & 1.000 & .409 \\
\hline & & Sig. (2-tailed) & . & .020 \\
\hline & & $\mathrm{N}$ & 32 & 30 \\
\hline & Writing & $\begin{array}{l}\text { Correlation } \\
\text { Coefficient }\end{array}$ & $409 *$ & 1.000 \\
\hline
\end{tabular}

*. Correlation is significant at the 0.05 level (2-tailed).

Table 3: Nonparametric Correlations 
As the aforementioned table 3 , it becomes evident to answer the second research question called how the students speaking do and writing ability show the correspondence are based on the final result of course elation coefficient and Sig. (2-tailed) above. First, The output from correlation coefficient shows 0,0409 which means that the correlation between the two variable is on 0,0409 or defined as moderate correlation while the sign of single star $(*)$ depict that the correlation is significant at the 0.05 level of significance about the analysis of Sig. (2-tailed), it shows the final output at 0,020 . Due to $0,020<0,05$ and $0.020>, 0.01$, defined as the correlation between the two productive skills is not significant or not average. To sum up, from the two aforementioned analysis, it can be concluded that the more someone mastered in speaking, the more their writing ability also increase, but the result may not be average or it won't simply the same such our course that we are mastered in speaking at 80 measurements the writing won't be exactly, can be quite higher or lower.

In the line of above- analysis and result, the output from correlative on coefficient depicted 0, 0409 addressed speaking and writing skill. It means that there is not a significant correlation coefficient between both of the skills. The skills final output that $0,020<0,05$ and $0.020>0.01$, meanwhile, it can be indicated that the correlation between the speaking and writing skill are not average although it was combined with some aspect as an organization, grammar, and vocabulary (table 1, 2, 3). It is also supported by (Yuzar and Rejeki 2020) which pointed out that perceptive skills have a strong relationship through a communicative form that students have well-vindicated in their reading skill becomes spearhead to writing proficiency. Besides, both of the productive skills include complicated and varied if they are integrating

In contrast, speaking and writing skill are connecting each other. Writing practices frequently bring out to increase speaking skills across the competence level (Bambang Yudi Cahyono 2017). Meanwhile, the importance of two productive skills in some particular focuses has been identified by many EFL teachers and researchers. The fundamental purpose of interlinked writing and speaking skills is also to develop proficiency in communication in learning a language (Elvita and Indrasari 2017). Beside of reaching the goal of communication, writing skill and writing motivation can be boosted through journal writing activity which identify their difficulties related to the writing in order to intensify interactive communication (Sholah 2019). For interlinking between speaking and writing, attractive media such as digital 
story help and endeavour the students' speaking performance inside or outside the classroom through the process of video production (Zuana 2018).

\section{Conclusion}

The researcher investigated to find out the relationship between students speaking ability and their writing skills. The aspects that are assessed on both skills through the organization, grammar, and vocabulary are used. Moreover, based on the result of the analysis, it was found that students speaking ability and their writing skills had a positive correlation but not significant or it won't simply the same such our course that we are mastered in speaking at 80 measurements the writing won't be exactly, can be quite higher or lower

Even though there was no significant between speaking and writing skills, but the medium correlation as the final results could be indicated that students who got good in speaking tended to get good scores in writing tests. This finding means that students are speaking and writing ability determined by each other in every sub subcomponent better reading the students have the better speaking they will perform.

\section{Implications of Findings}

Considering that the student's skills in writing have a higher score than their speaking ability, students should find their strategies to make balance the ability between both skill For writing skills, students who get good a level should not satisfy with the result. Nevertheless, they have to keep this achievement, and they should make an improvement to get perfect result especially in enriching the vocabulary, it can be seen that vocabulary is the element that has the lowest score either in writing or speaking ability.

\section{Bibliography}

Askia, Siska, and Konder Manurung. 2016. 'Improving Speaking Skills Through Active Learning Strategy of the Year Eight'. English Language Teaching Society 4 (2): 1-11.

Baba, Kyoko, Yuri Takemoto, and Miho Yokochi. 2013. 'Relationship between Second Language Speaking and Writing Skills and Modality Preference of University EFL 
Students'. Kinjo Gakuen University Working Papers: Social Sciences Edition 10 (1): 56-

68.

Bambang Yudi Cahyono. 2017. 'Writers Speak Better? Investigation of Indonesian Efl Students Speaking Ability and Writing Proficiency across Competence Levels'. Of Teaching \& Learning English in Multicultural Contexts 1 (1): 11-13.

Bozorgian, Hossein. 2012. 'The Relationship between Listening and Other Language Skills in International English Language Testing System'. Theory and Practice in Language Studies 2 (4): 657-63. https://doi.org/10.4304/tpls.2.4.657-663.

Crystal, D., C. C. M. Goh, and P. G. Doyle. 2015. How Do Speaking and Writing Support Each Other? New York: Routledge.

Development, Centre of Excellence for Early Childhood. 2010. Your Babys First Steps Toward Learning to Speak. Australia: Centre of Excellence for Early Childhood Development.

Elvita, R., and Indrasari. 2017. 'The Correlation between Students Speaking and Writing Ability among High School Students'. Leksika 11 (2): 2.

Fati, Meryem. 2013. 'The Effect of English Writing Proficiency in the Type and Amount of Errors Produced by Moroccan EFL Students .' International Journal of Education and Research $1(9): 1-12$.

Fatmawati, Dwitya Nadia, Slamet Santosa, and Joko Ariyanto. 2013. 'The Implementation of Think Talk Write Learning Strategy to Improve Student's Learn Activities in Biology Learning Class X-1 SMA Al Islam 1 Surakarta of 2009/2010 Academic Year'. BioPedagogi 2 (1): 1-15.

Florez, Mary Ann Cunningham. 1999. 'Improving Adult English Language Learners ' Speaking Skills'. Burns, no. June: 1-4.

Gass, S. M. \& Selinker, L. n.d. Language Acquisition: An Introduction Course. 3rd ed. New York. 
Hedge, T. 2000. Teaching and Learning in the Language Classroom. Oxford: Oxford University Press.

Hubert, M. 2008. 'The Relationship between Writing and Speaking In the U.S. University Spanish Language Classroom'. United State: Purdue University.

Hubert, Michael David. 2008. 'The Relationship between Writing and Speaking in the U.S.' Purdue University. https://search.proquest.com/openview/c265d74935ac81c694c4a8d577825e9e/1?pq -origsite=gscholar \&cbl=18750\&diss=y.

Hughes, R. 2002. Teaching and Researching Speaking. New York: Pearson Education.

Indrilla, Nidya, and Dyah Setyowati Ciptaningrum. 2018. 'An Approch in Teaching Writing Skills: Does It Offer a New Insight in Enhancing Students' Writing Ability'. A Journal on $\begin{array}{lllll}\text { Language } \quad \text { and } & \text { Language } & \text { (2): } & \text { 124-33. }\end{array}$ https://doi.org/doi.org/1024071/Ilt.2018.210210.

Joy Kreeft Peyton, and Kirsten Schaetzel. 2016. 'Teaching Writing to Adult English Language Learners: Lessons From the Field'. Journal of Literature and Art Studies 6 (11). https://doi.org/10.17265/2159-5836/2016.11.012.

Krashen, Stephen D. 2002. Second Language Acquisition and Second Language Learning. California: Pergamon Press.

Kucukoglu, Hulya. 2015. 'Improving Reading Skills through Effective Reading Strategies'. Elsevier: Social and Behavioral Science 70: 709-14. https://doi.org/10.1016/j.sbspro.2013.01.113.

Leong, Lai-Mei, and Seyedeh Masoumeh Ahmadi. 2017. 'An Analysis of Factors Influencing Learners' English Speaking Skill'. International Journal of Research in English Education 2 (1): 34-41. https://doi.org/10.18869/acadpub.ijree.2.1.34. 
Mahadi, Tengku Sepora Tengku, and Sepideh Moghaddas Jafari. 2012. 'Motivation, Its Types, and Its Impacts in Language Learning'. International Journal of Business and Social Science 3 (24): 230-35.

Mahmudah, Arrum Astria. 2019. 'The Relationship between Students Speaking Ability and Their Writing Achievement'. Jakarta: Syarif Hidayatullah State Islamic University.

Mangelsdorf, K. 1989. Parallels between Speaking and Writing in Second Language Acquisition. Texas: Bepress.

Mazouzi, S. 2013. 'Analysis of Some Factors Affecting Learners' Oral Performance. A Case Study: 3rd Year Pupils of Menaa's Middle Schools'. Briskra: Mohamed Khider University of Biskra.

Nan, Chengyu. 2018a. 'Implications of Interrelationship among Four Language Skills for High School English Teaching'. Journal of Language Teaching and Research 2. http://dx.doi.org/10.17507/jltr.0902.26.

- - . 2018b. 'Implications of Interrelationship among Four Language Skills for High School English Teaching'. Journal of Language Teaching and Research 2.

Naser, Muhammad, and Azmi. Latiff. 2019. 'Examining the Correlation Coefficient between Writing and Speaking Skills about Language Learning among Saudi EFL Undergraduates at the University of Tabuk'. Modern JOurnal of Language Teaching Method 1 (1). https://doi.org/10.26655/mjltm.2019.1.1.

Perera, Aparici, Rosado, and Salas. 2015. Written and Spoken Language Development across the Lifespan. Switzerland: Springer.

Quan, Zhu. 2014. 'Motivation for a Second or Foreign Language Learning'. SHS Web of Conferences 6: 04004. https://doi.org/10.1051/shsconf/20140604004. 
Rosenfeld, M., R. Courtney, and M. Fowles. 2004. 'Identifying the Writing Tasks Important for Academic Success at the Undergraduate and Graduate Levels.' In GRE Board Research Report No. 00-04 R. Princeton, NJ: Educational Testing Service.

Sadiku, Lorena Manaj. 2015. 'The Importance of Four Skills Reading, Speaking, Writing, Listening in a Lesson Hour'. European Journal of Language and Literature 1 (1): 29. https://doi.org/10.26417/ejls.v1i1.p29-31.

Sholah, Hanif Maulaniam. 2019. 'Enhancing EFL Learners' Writing Skill via Journal Writing'. Alsuna: Journal of Arabic and English Language 2 (2): 96-116. https://doi.org/10.31538/alsuna.v2i2.397.

Sulzby, Elizabeth, and William H Teale. 1985. 'Writing Development in Early Childhood'. Source: Educational Horizons 64 (1): 8-12.

Suryantari, Hadna. 2018. 'Children and Adults in Second-Language Learning'. Tell : Teaching of $\begin{array}{llllll}\text { English Language } & \text { Lnd }\end{array}$ https://doi.org/10.30651/tell.v6i1.2081.

Weissberg, R. 2006. Connecting Speaking and Writing in Second Language Writing Instruction. United Kingdom: Michigan series.

Wulandari, Indri Marantika, Alamsyah Harahap, and Gita Mutiara Hati. 2019. 'The Analysis of Students' Listening Learning Style (a Study of the 5th Semester Students at English Education Study Program of Universitas Bengkulu in Academic Year 2018/2019'. Journal of English Education and Teaching 3 (1): 42-52.

Young, R. F. 2002. 'Discourse Approaches to Oral Language Assessment'. Annual Review of Applied Linguistics 22: 243-62. 
Yuzar, E., and S. Rejeki. 2020. 'Correlation between Productive and Reseptive Skills: An Examination on ADFELPS Test Scores'. Study of Applied Linguistics and English Education 1 (2): 14-15.

Zuana, Muhammad Mujtaba Mitra. 2018. 'Digital Storytelling: An Attractive Media to Teach Narrative Text in Speaking Class'. Alsuna: Journal of Arabic and English Language 1 (1): 27-39. https://doi.org/10.31538/alsuna.v1i1.51. 